van Niel CB (1944) The culture, general physiology, morphology, and classification of the non-sulfur purple and brown bacteria. Bact Rev 8:1-118

Vincenzini M, Marchini A, Ena A. De Philippis R (1997) H2 and poly- $\beta$-hydroxybutyrate, two alternative chemicals from purple non sulfur bacteria. Biotechnol Lett 19:759-762

Wang AJ, Sun D, Cao GL, Wang HY, Ren NQ, Wu WM, Logan BE (2011) Integrated hydrogen prolls, and a

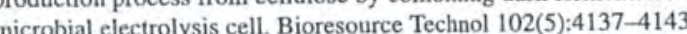

(2) process: dark- and photo-fermentation. Bioresource Technol 101:2049-2052 process. dark Yang ZM, Guo RB, Xual biomass residues. Int J Hydrogen Energ 36(5):3465-3470

extracted microalgal biom starch by a mixed Yokoi H, Mor S, Hrose Jusum, Rhodobacter sp. M-19. Biotechnol Lett 20(9):895-899 culture of Clast Hirose J, Hayashi S (2002) Microbial production of hydrogen from starchYokoi $\mathrm{H}$, Maki $\mathrm{R}$, wastes. Biomass Bioenerg 22:389-395

manufacturing wastes. Biomass Bioenerg 22:389-395 Zhu $\mathrm{H}$, Wakayama T, Asada $\mathrm{Y}$, Miyaketeric NH4+. Int J Hydrogen Energ 26(11):1149-1154

Zong W, Yu R, Ahang P, Fan M, Zhou Z (2009) Efficient hydrogen gas production from cassava Zong $W$, Yu $R$, Ahas Bioenerg 33:1458-1463

\section{Chapter 8 \\ Syntrophic Degradation of Fatty Acids \\ by Methanogenic Communities}

Alfons J.M. Stams, Petra Worm, Diana Z. Sousa, M. Madalena Alves, and Caroline M. Plugge

Abstract In methanogenic environments degradation of fatty acids is a key process in the conversion of organic matter to methane and carbon dioxide. For degradation of fatty acids with three or more carbon atoms syntrophic communities are required. This chapter describes the general features of syntrophic degradation in methanogenic environments and the properties of the microorganisms involved. Syntrophic fatty acid-degrading communities grow at the minimum of what is thermodynamically possible and they employ biochemical mechanisms to share the minimum amount of chemical energy that is available. Aggregation of the syntrophic fatty acid-degrading communities is required for high rate conversion.

Keywords Syntrophic $\cdot$ Methanogenesis $\bullet$ Fatty' acid degradation $\bullet$ Metabolic interaction $\bullet$ Hydrogen flux $\bullet$ Propionate degradation $\bullet$ Butyrate degradation $\bullet$ Energetics

A.J.M. Stams $(\mathbb{\square}) \cdot$ D.Z. Sousa

Laboratory of Microbiology, Wageningen University, Dreijenplein 10, Wageningen, HB 6703, The Netherlands

Institute for Biotechnology and Bioengineering, Center for Biological Engineering, University of Minho, Campus de Gualtar, Braga 4710-057, Portugal

e-mail: fons.stams@wur.nl

P. Worm $•$ C.M. Plugge

Laboratory of Microbiology, Wageningen University, Dreijenplein 10 Wageningen, HB 6703, The Netherlands

M.M. Alves

Institute for Biotechnology and Bioengineering. Center for Biological Engineering, University of Minho, Campus de Gualtar, Braga 4710-057, Portugal

P.C. Hallenbeck (ed.), Microbial Technologies in Advanced Biofuels Production, DOI 10.1007/978-1-4614-1208-3_8, @ Springer Science+Business Media, LLC 2012 


\subsection{Introduction}

Methanogenesis under controlled conditions in bioreactors is a sustainable way to conserve chemical energy in organic waste component as biogas. Methanogenesis is a microbial process in which metabolic interactions between different physiological types of microorganisms play a crucial role. Methanogens are rather restricted in their physiological abilities. These microorganisms belong to the archaea and derive energy from the conversion of a few simple substrates, which include $\mathrm{H}_{2} / \mathrm{CO}_{2}$, formate, methanol, methylated amines, and acetate (Liu and Whitmann 2008; Thauer et al. 2008). More complex substrates are not used by methanogens. Consequently, other microorganisms are required to degrade complex organic molecules to compounds that are substrates for methanogens (Schink and Stams 2006; McInerney et al. 2008). This results in a food chain as depicted in Fig. 8.1. Polymers in complex organic matter are first hydrolyzed by extracellular enzymes. Polysaccharides yield monomeric and oligomeric $\mathrm{C} 6$ and $\mathrm{C} 5$ sugars, while proteins are converted to mixtures of amino acids and small peptides. RNA and DNA are transformed to C5 sugars and nucleic bases purines (adenine and guanine) and pyrimidines (cytosine, thymine, and uracil). Lipids are degraded to glycerol and long-chain fatty acids. The general pattern of further anaerobic mineralization of organic matter is that fermentative bacteria degrade easily degradable compounds like sugars, amino acids, purines, pyrimidines, and glycerol to a variety of fatty acids, carbon dioxide, formate, and hydrogen. Then, higher fatty acids are degraded by so called acetogenic bacteria, finally to the methanogenic substrates. All these processes, fermentation,

Fig. 8.1 Schematic representation of methanogenic degradation of complex organic matter

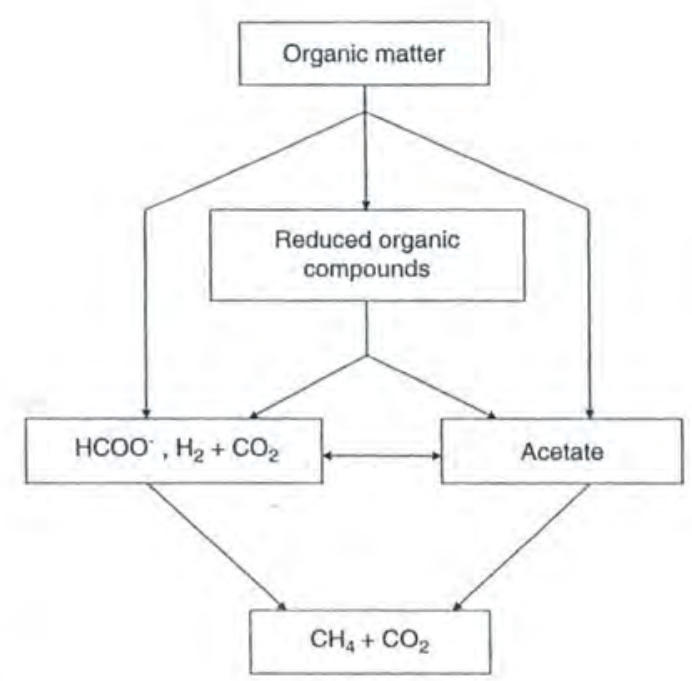

acetogenesis, and methanogenesis, take place simultaneously, but often, because of differences in growth rates and specific activities of the microorganisms involved, the processes are partially uncoupled, resulting in the accumulation of especially fatty acids. For complete mineralization of complex organic matter, acetogenic bacteria that degrade fatty acids play a crucial role. This chapter addresses the physiological properties of acetogenic bacteria that degrade propionate, butyrate, and higher fatty acids. Propionate and butyrate are important intermediates in the anaerobic fermentation of sugars and amino acids (Schink and Stams 2006: Stams 1994), while long-chain fatty acids are formed in the hydrolysis of lipids and fats (McInerney 1988; Sousa et al. 2009). To optimize methanogenesis in bioreactors especially the metabolic interactions of syntrophic communities need to be understood.

\subsection{General Features of Syntrophic Fatty Acid Conversion}

Bacteria that degrade and grow on fatty acids have to deal with the unfavorable energetics of the conversion processes. Table 8.1 illustrates the conversion of some fatty acids to the methanogenic substrates acetate and hydrogen. It is evident that bacteria can only derive energy for growth from these conversions when the product concentrations are kept low. This results in an obligate dependence of acetogenic

Table 8.1 Standard Gibbs free energy changes for some of the reactions involved in syntrophic fatty acid degradation metabolism

\begin{tabular}{|c|c|}
\hline \multicolumn{2}{|l|}{ Fatty acid oxidation } \\
\hline Propionate $^{-}+3 \mathrm{H}_{2} \mathrm{O} \rightarrow$ acetate $-\mathrm{HCO}_{3}^{-}+\mathrm{H}^{+}+3 \mathrm{H}_{2}$ & 76 \\
\hline Butyrate $+2 \mathrm{H}_{2} \mathrm{O} \rightarrow 2$ acetate $^{-}+\mathrm{H}^{+}+2 \mathrm{H}_{2}$ & 48 \\
\hline Caproate $^{-}+4 \mathrm{H}_{2} \mathrm{O} \rightarrow 3$ acetate $^{-}+14 \mathrm{H}_{2}+2 \mathrm{H}^{+}$ & 96 \\
\hline Palmitate $^{-}+14 \mathrm{H}_{2} \mathrm{O} \rightarrow$ 8acetate $-14 \mathrm{H}_{2}+7 \mathrm{H}^{-}$ & 353 \\
\hline Stearate $^{-}+16 \mathrm{H}_{2} \mathrm{O} \rightarrow 9$ acetate $^{-}+16 \mathrm{H}_{2}+8 \mathrm{H}^{+}$ & 404 \\
\hline Oleate $^{-}+16 \mathrm{H}_{2} \mathrm{O} \rightarrow 9$ acetate $^{-}+15 \mathrm{H}_{2}+8 \mathrm{H}^{\prime}$ & 338 \\
\hline \multicolumn{2}{|c|}{ Hydrogen utilization by methanogens, homoacetogens, and sulfate reducers } \\
\hline $4 \mathrm{H}_{2}+\mathrm{HCO}_{3}^{-}+\mathrm{H}^{+} \rightarrow \mathrm{CH}_{4}+3 \mathrm{H}_{2} \mathrm{O}$ & 136 \\
\hline $4 \mathrm{H}_{2}+2 \mathrm{HCO}_{3}^{-}+\mathrm{H}^{+} \rightarrow$ acetate $+4 \mathrm{H}_{2} \mathrm{O}$ & 105 \\
\hline $4 \mathrm{H}_{2}+\mathrm{SO}_{4}{ }^{2-}+\mathrm{H}^{*} \rightarrow \mathrm{HS}+4 \mathrm{H}_{2} \mathrm{O}$ & 152 \\
\hline \multicolumn{2}{|l|}{ Acetate utilization by methanogens and sulfate reducers } \\
\hline Acetate $+\mathrm{H}_{2} \mathrm{O} \rightarrow \mathrm{HCO}_{3}^{-}+\mathrm{CH}_{4}$ & 31 \\
\hline Acetate $+\mathrm{SO}_{4}^{2-}+2 \mathrm{H}_{2} \mathrm{O} \rightarrow \mathrm{HS}^{-}+2 \mathrm{HCO}_{3}^{-}$ & 47 \\
\hline \multicolumn{2}{|l|}{ Intracellular redox conversions } \\
\hline $2 \mathrm{Fd}_{(\text {sed })}+2 \mathrm{H}^{+} \rightarrow 2 \mathrm{Fd}_{(\mathrm{ost})}+\mathrm{H}_{2}$ & 3 \\
\hline $\mathrm{NADH}+\mathrm{H}^{*} \rightarrow \mathrm{NAD}^{+}+\mathrm{H}_{2}$ & 18 \\
\hline $\mathrm{FADH}_{2} \rightarrow \mathrm{FAD}+\mathrm{H}_{2}$ & 37 \\
\hline
\end{tabular}

Standard Gibbs energies of formation of obtained from Thauer et al (1977); for palmitate, steare. and oleate standard Gibbs energies of formation were caleulat from the structures of the conpounds using a group contribution method described by Mavrovouniots (1991) 
bacteria on methanogenic archaea for product removal. As the methanogens obtain their substrates for growth from the acetogens, syntrophic communities are enriched with propionate, butyrate, and higher fatty acids.

Obligate syntrophic communities of acetogenic bacteria and methanogenic archaea have several unique features: (1) they degrade fatty acids coupled to growth, while neither the archaeon nor the bacterium alone is able to degrade these compounds; (2) intermicrobial distances influence biodegradation rates and specific growth rates, which in nature results in the self-aggregation of bacteria and archaea to compact aggregates; (3) the syntrophic communities grow in conditions that are close to thermodynamical equilibrium; and (4) the communities have evolved biochemical mechanisms that allow sharing of chemical energy. There still is discussion whether hydrogen and formate are the primary compounds for interspecies electron transfer, and it is still unclear what their relative importance is. Here, mainly syntrophy in terms of interspecies hydrogen transfer is discussed, but where relevant interspecies formate transfer will be discussed as well.

In syntrophic fatty acid-degrading communities, hydrogen has to diffuse from the acetogen to the methanogen. Therefore, the specific flux of hydrogen can be derived from the Fick's diffusion law (8.1) (Ishii et al. 2006; Schink and Thauer 1988).

$$
J=D_{\mathrm{H}_{2}} \times\left\{\left[\mathrm{H}_{2}\right]_{\text {acelogen }}-\left[\mathrm{H}_{2}\right]_{\text {methanogen }}\right\} / \text { day. }
$$

$J$ : specific interspecies hydrogen flux $\left(\mu \mathrm{mol} / \mu \mathrm{m}^{2} / \mathrm{s}\right)$

$D_{\text {: }}$ diffusion constant for hydrogen $\left(4.9 \times 10^{-5} \mathrm{~m}^{2} / \mathrm{s}\right.$ at $\left.298 \mathrm{~K}\right)$,

$\left[\mathrm{H}_{2}\right]^{\circ}$ hydrogen concentration at the outside surface of the acetogen $\left[\mathrm{H}_{2}\right]_{\text {acetogere }}:$ hydr
$\left(\mu \mathrm{mol} / \mu \mathrm{m}^{3}\right)$.

$\left[\mathrm{H}_{2}\right]$ : hydrogen concentration at the outside surface of the methanogen cell $\left(\mu \mathrm{mol} / \mu \mathrm{m}^{3}\right)$.

$D:$ average distance between the acetogen and the methanogen $(\mu \mathrm{m})$.

The flux of hydrogen between the two species can be calculated by multiplying the $\mathrm{J}$ value by the total surface area of hydrogen-releasing acetogens.

The total hydrogen flux is directly dependent on the surface area of the acetogen, the diffusion constant of hydrogen, the concentration difference of hydrogen between the acetogens and the methanogens, and the distance between the two microorganisms The maximum difference in concentration between the acetogens and the methanogens is determined by the thermodynamical borders of the conversions carried out by these microorganisms. These thermodynamical borders refer to nongrowing conditions; if the microorganisms have to conserve metabolic energy for growth, the difference in concentration is smaller. The highest concentration that can be formed by the acetogen and the lowest concentration that can be reached by the methanogen can be calculated from data in Table 8.1, provided that the concentrations of other compounds are known.

Such calculations were made for the degradation of a number of compounds in different anoxic environments (Conrad et al, 1986). Cord-Ruwisch et al. (1988) showed that the measured threshold values for hydrogen of the different types of hydrogen-utilizing microorganisms correlated with the values expected from the $\Delta G^{\circ}$ 's. The threshold value for hydrogen of growing methanogens and sulfate reducers are 3-10 and 1-2 $\mathrm{Pa}$, respectively. These differences explain why the growth rate of acetogenic bacteria depends on the type of hydrogenotrophic microorganism. The maximum specific growth rates of propionate- and butyratedegrading acetogenic bacteria in coculture with methanogens were 0.10 , and 0.19 / day, respectively, while in coculture with sulfate reducers these values were 0.19 and 0.31/day, respectively (Boone and Bryant 1980; McInerney et al. 1979; Mountfort and Bryant 1982).

The diffusion distance between the acetogens and methanogens is determined by the biomass density. Clustering of cells will lead to increased fluxes (Schink an Thauer 1988). Assuming that bacteria have a diameter of $2 \mu \mathrm{m}$, it can be calculated that in cultures containing $10^{8}, 10^{9}, 10^{10}$, and $10^{11} \mathrm{cells} / \mathrm{ml}$ the average intermicrobial distances are about $25,10,4$, and $0.5 \mu \mathrm{m}$, respectively. Therefore, in syntrophic conversion the activity per cell, and consequently the specific growth rate, wil increase with decreasing intermicrobial distances. This effect may explain the apparent long lag-phases often observed during subcultivation of syntrophic cultures. In methanogenic granular sludge the cell densities are extremely high: up to $10^{12} \mathrm{CFU} / \mathrm{ml}$ wet sludge (Grotenhuis et al. 1991; Dolfing et al. 1985). Such high cell densities are favorable for interspecies hydrogen transfer, resulting in very high methanogenic activities with fatty acids as substrates. In propionate-adapted methanogenic granules, microbial structures were observed in which the distances between propionate-oxidizing bacteria and methanogens were in the micrometer range (Grotenhuis et al. 1991). Disrupture of the structure led to a reduction of the propionate degradation rate by $90 \%$, while the acetate degradation rate by methanogens was largely unaffected. Moreover, shortening of intermicrobial distances by the creation of artificial precipitates (Stams et al. 1992) or by the addition of extra methanogens (Dwyer et al. 1988; Schmidt and Ahring 1993) led to increased methane formation rates with propionate and butyrate.

Using the van't Hoff equation, Gibbs free energy changes at different temperatures can be calculated. $\Delta G$ and $\Delta H$ values have been listed by Thauer et al. (1977) and Chang (1977), respectively. A change in temperature has an effect on the reaction-dependent part and on the concentration-dependent part of the $\Delta G^{\prime}$ values. Calculations of $\Delta G^{\prime}$ values at different temperatures show that hydrogen formation becomes energetically more favorable at higher temperatures, whereas hydrogenconsuming reactions become less favorable. Consequently, lower hydrogen partial pressures can be reached by the methanogens at lower temperatures. The opposite is true for the highest hydrogen concentrations that can be formed by the acetogens. These calculations fit with the lowest and highest hydrogen partial pressures which have been measured with mesophilic and thermophilic methanogens and acetogens. An increase in temperature affects the flux of hydrogen in two ways: the diffusion coefficient becomes higher and the concentration gradient between the methanogen and the acetogen becomes steeper. 


\subsection{Syntrophic Propionate-Degrading Bacteria}

Boone and Bryant (1980) described Syntrophobacter wolinii a bacterium that grows in syntrophic association with methanogens or sulfate-reducing bacteria. Since then, several other mesophilic and thermophilic bacteria that grow in syntrophy with methanogens have been described (Table 8.2). These include Gram-negative bacteria (Syntrophobacter and Smithella) and Gram-positive bacteria (Pelotomaculum and Desulfotomaculum) (McInerney et al. 2008). Phylogenetically, both groups are related to sulfate-reducing bacteria and some indeed grow by sulfate reduction (Table 8.2). Syntrophobacter and Desulfotomaculum species are able to reduce sulfate, but Smithella and Pelotomaculum are not. Most syntrophic propionate-degrading bacteria are able to grow in pure culture by fermentation of fumarate or pyruvate. Fermentative growth or sulfate-dependent growth has been used to successfully obtain the bacteria in pure culture. The only exceptions are Pelotomaculum schinkii (de Bok et al. 2005) and Pelotomaculum propionicicum (Imachi et al. 2007), which seem to be true propionate-degrading syntrophs. Pure cultures of these strains are not available: $P$. thermopropionicum and Desulfotomaculum thermobenzoicum (subsp. thermopropionicum) are moderately thermophilic and grow in syntrophy with thermophilic methanogens (Imachi et al. 2002; Plugge et al. 2002). A marine propionate-degrading syntrophic community has been described, but the identity of the propionate-degrading bacterium is not known (Kendall et al. 2006).

Two pathways for propionate metabolism are known, the methylmalonyl-CoA pathway (Fig. 8.2b) and a dismutation pathway. In the latter pathway two propionate molecules are converted to acetate and butyrate, the butyrate being degraded to acetate and hydrogen as described below. Thus far, this pathway is only found in Smithella propionica (Liu et al. 1999; de Bok et al. 2001). The methylmalonyl-CoA pathway is found in the other syntrophic propionate-oxidizing bacteria (McInerney et al. 2008). In the methylmalonyl-CoA pathway, propionate is first activated to propionyl-CoA and then carboxylated to methylmalonyl-CoA. Methylmalonyl$\mathrm{CoA}$ is rearranged to form succinyl-CoA, which is converted to succinate. Succinate is oxidized to fumarate, which is then hydrated to malate and oxidized to oxaloacetate. Pyruvate is formed by decarboxylation, and is further oxidized in a HS-CoAdependent decarboxylation to acetyl-CoA and finally to acetate.

\subsection{Syntrophic Butyrate- and LCFA-Degrading Bacteria}

McInerney et al. (1981) enriched and characterized Syntrophomonas wolfei, a bacterium that degrades butyrate and some other short-chain fatty acids in syntrophic association with methanogens. Several other bacteria since then have been described that grow with butyrate or higher fatty acids in syntrophy with hydrogenotrophic methanogens or sulfate reducers (Table 8.3). Thus far, Algorimarina butyrica is the only psychrophilic bacterium that is known to degrade butyrate in syntrophy with

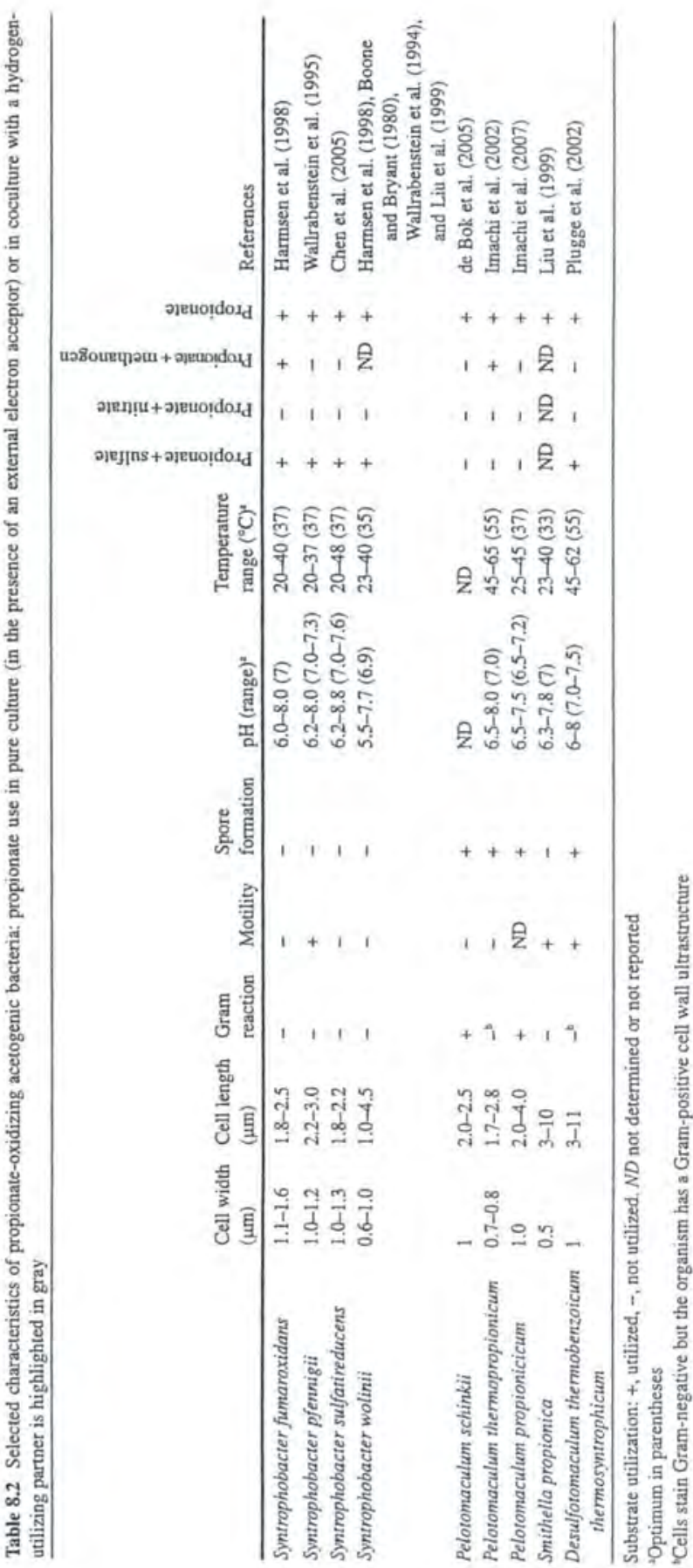


a propionate

$\rightarrow$ HS-COA ---1

$$
\text { 2[H] }
$$

... HS-COA

$$
\text { acetate }
$$

Fig. 8.2 Pathways of propionate (a) and butyrate (b) degradation by acetogenic bacteria growing in syntrophic association with methanogens. ATP production by substrate-level phosphorylation

methanogens (Kendall et al. 2006). This marine bacterium is not able to grow on medium-chain fatty acids like valerate or caproate or longer fatty acids such as palmitate. Mesophilic bacteria capable of syntrophic fatty acid metabolism are mainly species of Syntrophomonas, though Syntrophomonas bryantii was previously named Syntrophospora bryantii and Clostridium bryantii (McInerney et al. 2008; Sousa et al. 2009; Wu et al. 2006a). The only exception is Syntrophus aciditrophicus, a syntrophic benzoate-degrading bacteria that it is also able to degrade medium- and long-chain fatty acids in coculture with a methanogen (Jackson et al. 1999). Thermophilic syntrophic butyrate-degrading bacteria are Thermosyntropha lipolytica (Svetlitshnyi et al. 1996) and Syntrophothermus lipocalidus (Sekiguchi et al. 2000). None of the fatty acid-degrading bacteria that grow syntrophically with

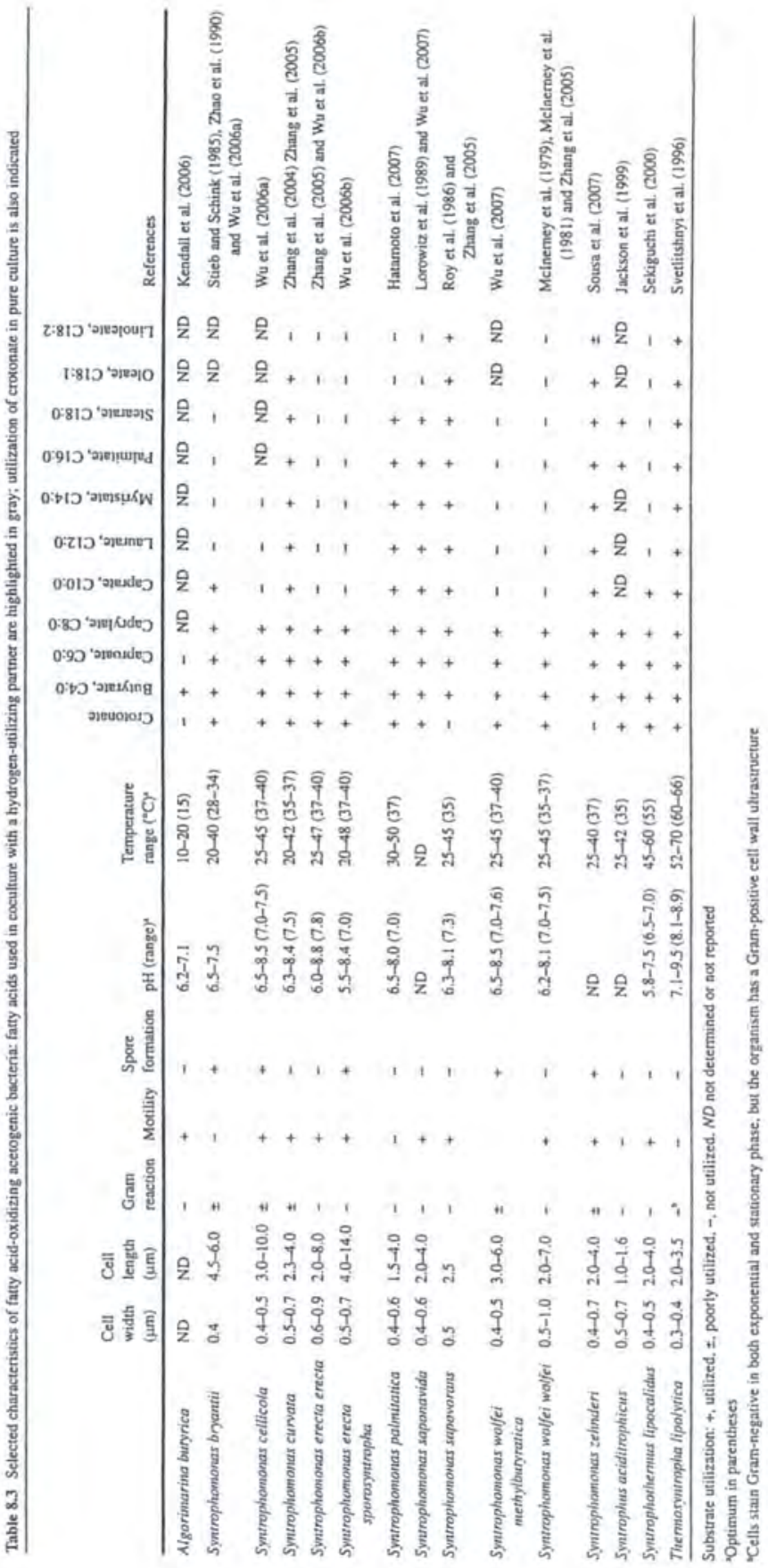


methanogens has been described to be able to reduce sulfate. Most fatty acid degraders are able to ferment crotonate, which was used to obtain pure cultures. However, Synthrophomonas sapovorans and Syntrophomonas zehnderi are not able to fermen crotonate, and are only available in syntrophic methanogenic cocultures (Roy et al. 1986; Sousa et al. 2007).

Butyrate and longer chain fatty acids are degraded via so-called $\beta$-oxidation (McInerney et al. 2008; Schink and Stams 2006). In a series of reactions acetyl groups are cleaved off yielding acetate and hydrogen. To metabolize fatty acids, first activation to a HS-CoA derivative takes place. The HS-CoA-derivative is then dehydrogenated to form an enoyl-CoA. After water addition, a second dehydrogenation takes place to form a ketoacylacetyl-CoA. After hydrolysis acetyl-CoA and an acyl-CoA are formed, which enters another cycle of dehydrogenation and the cleaving off of acetyl-CoA. Figure $8.2 \mathrm{~b}$ shows the pathway of syntrophic butyrate degradation.

\subsection{Energetics of Syntrophic Degradation}

Based on the energy released by the hydrolysis of ATP and the concentrations of adenylate molecules in growing bacteria, it is estimated that a free energy change of -60 to $-70 \mathrm{~kJ}$ is required for the synthesis of $1 \mathrm{~mol}$ of ATP under physiological conditions. This amount of energy does not need to be supplied in one single step, as is the case in substrate-level phosphorylation, but can be accomplished in smaller amounts, for example, by proton or sodium translocation across the cytoplasmic membrane. If a ratio of three protons translocated per ATP is assumed, about $20 \mathrm{~kJ}$ energy difference is the smallest energy quantum that may allow energy conservation and growth. It can be calculated that under in situ conditions about $20 \mathrm{~kJ}$ energy difference (the equivalent of $1 / 3 \mathrm{ATP}$ ) is available for bacteria that grow syntrophically on propionate or butyrate. Following the pathway of propionate and butyrate degradation (Fig. 8.2a, b), seemingly one ATP can be formed from the conversion of the energy rich HS-CoA esters. However, syntrophic bacteria encounter an energetic barrier in the formation of hydrogen from intracellular redox mediators. In the propionate oxidation pathway three oxidation steps are involved, succinate oxidation to fumarate, malate oxidation to oxaloacetate and pyruvate oxidation to acetyl$\mathrm{CoA}$. In these oxidation steps electrons are released at the energetic level of $\mathrm{FADH}_{2}$, $\mathrm{NADH}$, and reduced ferredoxin, respectively, and need to be coupled to hydrogen formation (Table 8.1). Similarly, in butyrate oxidation electrons are released at the energetic level of $\mathrm{FADH}_{2}$ and $\mathrm{NADH}$, in the oxidation of butyryl-CoA to crotonyl$\mathrm{CoA}$ and of hydoxybutyryl-CoA to acetoacetyl-CoA, respectively.

Methanogens are able to bring the hydrogen level down to about $1 \mathrm{~Pa}$ under nongrowing conditions. At this hydrogen level, NADH oxidation and reduced ferredoxin oxidation coupled to hydrogen formation is energetically feasible for the fatty acid degraders. However, at a hydrogen partial pressure of $1 \mathrm{~Pa} \mathrm{FADH}_{2}$ oxidation still is not feasible. Therefore, propionate- and butyrate-oxidizing bacteria have to invest metabolic energy to push this reaction. The biochemical mechanism that is used for this is not completely clear. The complete genome sequences of $S$. aciditrophicus, $S$. wolfei, Syntrophobacter fumaroxidans, and $P$. thermopropionicum have been reported. From the predicted localization of key enzymes involved a speculation of the biochemical mechanisms of reversed electron flow can be made.

The mechanism to drive succinate oxidation to fumarate $\left(E^{\circ \prime}=+33 \mathrm{mV}\right)$ during syntrophic growth is possibly similar to the mechanism of energy conservation during fumarate respiration in Wolinella succinogenes, but operating in reversed mode (Müller et al. 2010). Bacillus subtilis also uses reversed electron transfer in succinate oxidation by coupling it to menaquinone reduction $\left(E^{\circ \prime}=-80 \mathrm{mV}\right)$. Menaquinone binds cytochrome $\mathrm{b}$ close to the outside of the cell membrane. When reduced menaquinone is oxidized at the cytoplasmic side of the membrane and inward movement of protons is achieved (Schirawski and Unden 1998). In syntrophic propionate metabolism, menaquinone oxidation is linked to a membrane-bound hydrogenase or formate dehydrogenase. Genome and biochemical analysis of S. fumaroxidans revealed the presence of a membrane integrated succinate dehydogenase gene cluster containing menaquinone (Sfum_1998, 1999, and 2000) and several periplasmic and cytoplasmic hydrogenases and formate dehydrogenases (Table 8.4a) (Müller et al. 2010; Worm et al. 2010). A requirement of $2 / 3$ ATP for reversed electron transport was determined. This is schematically presented in Fig. 8.3. A similar and phylogenetically related succinate dehydrogenase gene cluster was found in $P$. thermopropionicum (Kosaka et al. 2006, 2008). This indicates that succinate oxidation to fumarate requires a proton gradient over the membrane and the investment of ATP to form hydrogen at the outside of the cytoplasmic membrane. In syntrophic communities the methanogens directly scavenge the hydrogen formed. Menaquinone found in $S$. wolfei possibly functions as the electron carrier between a membraneassociated butyryl-CoA dehydrogenase and a cytoplasmically oriented hydrogenase (Muiller et al. 2010). Inward movement of protons by the quinone loop is compensated by proton extrusion by a membrane-bound ATPase, similar to succinate oxidation in syntrophic propionate oxidation, though in S. aciditrophicus hydrogenases seem to be located at the inner aspect of the cell (Table 8.4). An alternative mechanism to produce $\mathrm{H}_{2}$ from thermodynamically difficult substrates comes from recent studies with Clostridium kluyveri (Herrmann et al, 2008). C. kluyveri ferments ethanol and acetate to butyrate and some hydrogen. A soluble enzyme complex in $C$. kluyveri couples the energetically favorable reduction of crotonyl-CoA to butyrylCoA by NADH with the unfavorable reduction of ferredoxin (Fd) by NADH:

Crotonyl $-\mathrm{CoA}+\mathrm{Fd}_{(0 \mathrm{x})}+2 \mathrm{NADH}+2 \mathrm{H}^{+} \rightarrow$ butyryl $-\mathrm{CoA}+\mathrm{Fd}_{(\text {(red })}+2 \mathrm{NAD}^{+}$.

The reverse mechanism may be involved in syntrophic butyrate degradation, though in that case it remains unclear how the bacteria form reduced ferredoxin needed for that conversion. 
Table 8.4 Genes annotated as formate dehydrogenase and hydrogenase in the genomes of Syntrophobacter fumaroxidans (a) and Syntrophus aciditrophicus (b) (http://img.jgi.doe.gov).

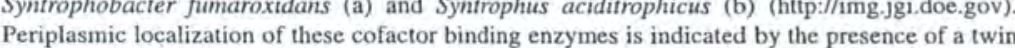
\begin{tabular}{l} 
Periplasmic localization of these cofactor binding enzymes is indicated by the presence of a twin \\
arginine translocation motif in the $\mathrm{N}$-terminal amino acid sequence \\
Locus tag Localization \\
\hline Enzyme
\end{tabular}

(a) Genes annotated as formate dehydrogenase or hydrogenase in the genome

(n)

of $S$. fumaroxidan

Formate dehydrogenase

Sfum_2706, Sfum_2705*

Cytoplasm

W, Se

Formate dehydrogenase

Sfum_1274, Sfum_12732

Periplasm

W, Se

Formate dehydrogenase

Sfum_3509

Periplasm

W, Se

Sfum_0031, Sfum_0030 $\quad$ Periplasm $\quad$ W/Mo, Se

Sfum_0844 Periplasm $\quad \mathrm{Fe}$

Hydrogenase

Sfum_295

Periplasm

$\mathrm{Fe}, \mathrm{Ni}, \mathrm{Fe}$

Hydrogenase

Sfum_222

Cytoplasm

Cytoplasm

$\mathrm{Ni}, \mathrm{Fe}$

Hydrogenase Sfum_3537 $\quad$ Cytoplasm

Periplasm

$\mathrm{Ni}, \mathrm{Fe}, \mathrm{Se}$

(b) Genes annotated as formate dehydrogenase or hydrogenase in the genome

Formate dehydrogenase Syn_00635, Sfum_00634 $\quad$ Periplasm

Formate dehydroger

$\begin{array}{llll}\text { Formate dehydrogenase } & \text { Syn_00630,Syn_00629: } & \text { Cytoplasm } & \text { W/Mo, Se } \\ \text { Formate dehydrogenase } & \text { Syn_02137, Syn_002138 } & \text { Cytoplasm } & \text { W/Mo, Se }\end{array}$

$\begin{array}{llll}\text { Formate dehydrogenase } & \text { Syn_02137, Syn_002138* } & \text { Cytoplasm } & \text { W/Mo, Se } \\ \text { Formate dehydrogenase } & \text { Syn_00602,Sf_00603* } & \text { Periplasm } & \text { W/Mo,Se }\end{array}$

$\mathrm{W} / \mathrm{Mo}, \mathrm{Se}$

Hydrogenase

Syn_01370

Periplasm

Cytoplasm

$\mathrm{Ni}, \mathrm{Fe}$

Selenocysteine residues were predicted by recognition of a TGA with a downstream sequence Selring a rester by Zhang and Gladyshev (2005)

Fig. 8.3 Hypothetical mechanism of membrane integrated, ATP-depende succinate oxidation in propionate-degrading acetogenic bacteri

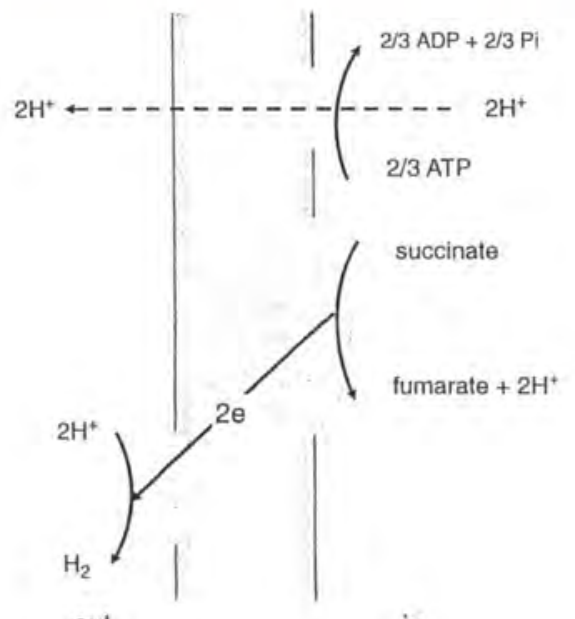

A special mechanism of propionate and butyrate activation exists in syntrophic bacteria. In general, carboxylic acids are activated by kinases or thiokinases and require one ATP. S. fumaroxidans and $P$, thermopropionicum activate propionate through HS-CoA-transferase (Kosaka et al. 2006, 2008; Plugge et al. 1993). Sequence analysis of these genes reveals a very high homology between the HS-CoA transferase of both microorganisms (79\% sequence identity, Sfum_1163 and Pth_1771). In butyrate-oxidizing syntrophs, the initial activation of butyrate also occurs by HS-CoA transferase (Wofford et al. 1986). However, no clear sequence similarity exists between the HS-CoA transferases of propionate oxidizers and butyrate oxidizers.

\subsection{Conclusions and Perspectives}

Syntrophic communities operate in conditions that are close to thermodynamical equilibrium. This implies that changes in environmental conditions affect conversion rates and growth of the syntrophic communities. In anaerobic waste and wastewater treatment disturbances in operation of the process results in the accumulation of fatty acids, coinciding with a $\mathrm{pH}$ decrease that may be detrimental for the whole process. On the other hand, the characteristics of syntrophic degradation may also be used to optimize degradation, as was done to develop a process for efficient anaerobic conversion of wastewaters that contain large amounts of lipids and longchain fatty acids (Alves et al. 2009).

Several bacteria have been isolated and characterized that have the ability to degrade fatty acids in syntrophy with hydrogen-consuming methanogens. The biochemical pathways that these bacteria employ and the energetic barriers that these bacteria have to overcome are known. However, the exact biochemical mechanisms by which these bacteria overcome the energetic barriers are not yet fully understood. Genome sequence information can be used to unravel how these fatty aciddegrading bacteria regulate their metabolism in changing environmental conditions.

Degradation of organic waste to biogas, which consists mainly of methane and carbon dioxide, is a unique process. Irrespectively of the microorganisms involved and the pathways that they employ, a variety of organic compounds can be easily and completely degraded to biogas. The substrate conversion rates and growth rates of fatty acid-degrading communities determine the overall efficiency of the methanogenic process. However, to make anaerobic digestion unfailing and to increase the overall rates of methanogenesis, the metabolic interactions between bacteria and archaea deserve to be further explored.

Acknowledgments Our research was funded by grants of the Chemical Science (CW) and the Earth and Life Sciences (ALW) divisions and the Technical Science Foundation (STW) of the Netherlands Science Foundation (NWO). Research of D.Z. Sousa was financed by Fundação para a Ciência e Tecnologia (FCT) and Fundo Social Europeu (FSE) (SFRH/BD/8726/2002), and by the Wageningen Institute for Environmental and Climate Research (WIMEK). 


\section{References}

Alves MM, Pereira MAA, Sousa DZ, Cavaleiro AJ, Picavet M, Smidt H, Stams AJM (2009) Waste-lipids to energy: how to optimize methane production from long-chain fatty acid (LCFA). Microbiol Biotechnol 2:538-550

Boone DR, Bryant MP (1980) Propionate-degrading bacterium, Syntrophobacter wolinii sp. nov. gen. nov. from methanogenic ecosystems. Appl Environ Microbiol 40:626-632

Chang R (1977) Physical chemistry with applications to biological systems. Macmillan Publishing Co., New York

Chen SY, Liu XL, Dong XZ (2005) Syntrophobacter sulfatireducens sp. nov., a novel syntrophic propionate-oxidizing bacterium isolated from UASB reactors. Int J Syst Evol Microbio $55: 1319-1324$

Conrad R, Schink B, Phelps TJ (1986) Thermodynamics of $\mathrm{H}_{2}$-consurning and $\mathrm{H}_{2}$-producing metabolic reactions in diverse methanogenic environments under in situ conditions. FEMS Microbio Ecol 38:353-360

Cord-Ruwisch R, Seitz HJ, Conrad R (1988) The capacity of hydrogenotrophic anaerobic bacteria to complete traces of hydrogen depends on the redox potential of the terminal electron acceptors. Arch Microbiol 149:350-357

de Bok FAM, Stams AJM, Dijkema C, Boone DR (2001) Pathway of propionate oxidation by a syntrophic culture of Smithella propionica and Methanospirillum hungatei. Appl Environ Microbiol 67:1800-1804

de Bok FAM, Harmsen HJM, Plugge CM, de Vries MC, Akkermans ADL, de Vos WM, Stams AJM (2005) The first true obligately syntrophic propionate-oxidizing bacterium, Pelotomaculum schinkii sp. nov., co-cultured with Methanospirillum hungatei, and emended description of the genus Pelotomaculum. Int J Syst Evol Microbiol 55:1697-1703

Dolfing J, Griffioen A, van Neerven ARW, Zevenhuizen LPTM (1985) Chemical and bacteriological composition of granular methanogenic sludge. Can J Microbiol 31:744-750

Dwyer DF, Weeg-Aerssens E, Shelton DR. Tiedje JM (1988) Bioenergetic conditions of butyrate metabolism by a syntrophic, anaerobic bacterium in coculture with hydrogen-oxidizing methanogenic and sulfidogenic bacteria. Appl Environ Microbiol 54:1354-1359

Grotenhuis JTC, Smit M, Plugge CM, Xu Y, Van Lammeren AAM, Stams AJM, Zehnder AJB (1991) Bacteriological composition and structure of granular sludge adapted to different substrates. Appl Environ Microbiol 57:1942-1949

Harmsen HJM, van Kuijk BLM, Plugge CM, Akkermans ADL, de Vos WM, Stams AJM (1998) Syntrophobacter fumaroxidans sp. nov., a syntrophic propionate-degrading sulfate-reducin bacterium. Int J Syst Bacteriol 48:1383-1387

Hatamoto M, Imachi H, Fukayo S, Ohashi A, Harada H (2007) Syntrophomonas palmitatica sp. nov., an anaerobic, syntrophic, long-chain fatty-acid-oxidizing bacterium isolated from methanogenic sludge. Int J Syst Evol Microbiol 57:2137-2142

Herrmann G, Jayamani E, Mai G, Buckel W (2008) Energy conservation via electron-transferring flavoprotein in anaerobic bacteria. J Bacteriol 90:784-791

Imachi H, Sekiguchi Y, Kamagata Y, Hanada S, Ohashi A, Harada H (2002) Pelotomaculum thermopropionicum gen. nov., sp. nov., an anaerobic, thermophilic, syntrophic propionate-oxidizing bacterium. Int J Syst Evol Microbiol 52:1729-1735

Imachi H, Sakai S, Ohashi A, Harada H, Hanada S, Kamagata Y, Sekiguchi Y (2007) Pelotomaculum propionicicum sp. nov., an anaerobic, mesophilic, obligately syntrophic, propionate-oxidizing bacterium. Int J Syst Evol Microbiol 57:1487-1492

Ishii S, Kosaka T, Hotta Y, Watanabe K (2006) Simulating the contribution of coaggregation to interspecies hydrogen fluxes in syntrophic methanogenic consortia. Appl Environ Microbiol 72:5093-5096

Jackson BE, Bhupathiraju VK, Tanner RS, Woese CR, McInerney MJ (1999) Syntrophus aciditrophicus sp. nov., a new anaerobic bacterium that degrades fatty acids and benzoate in syntrophic association with hydrogen-using microorganisms. Arch Microbiol 171:107-114
Kendall MM, Liu Y, Boone DR (2006) Butyrate- and propionate-degrading syntrophs from permanently cold marine sediments in Skan Bay, Alaska, and description of Algorimarina butyrica gen. nov., sp. nov. FEMS Microbiol Lett 262:107-114

Kosaka T, Uchiyama T, Ishil S, Enoki M, Imachi H, Kamagata Y, Ohashi A, Harada H, Ikenaga H, Watanabe K (2006) Reconstruction and regulation of the central catabolic pathway in the thermophilic propionate-oxidizing syntroph Pelotomaculum thermopropionicum. J Bacteriol 188:202-210

Kosaka T, Kato S, Shimoyama T, Ishii S, Abe T, Watanabe K (2008) The genome of Pelotomaculum thermopropionicum reveals niche-associated evolution in anaerobic microbiota. Genome Res 18:442-448

Liu Y, Whitmann WB (2008) Metabolic, phylogenetic, and ecological diversity of the methanogenic archaea. Ann N Y Acad Sci 1125:171-189

Liu Y, Balkwill DL, Aldrich HC, Drake GR, Boone DR (1999) Characterization of the anaerobic propionate-degrading syntrophs Smithella propionica gen. nov., sp. nov. and Syntrophobacter wolinii. Int J Syst Bacteriol 49:545-556

Lorowitz WH, Zhao HX, Bryant MP (1989) Syntrophomonas wolfei subsp saponavida subsp. nov.. a long-chain fatty-acid degrading, anaerobic, syntrophic bacterium - Syntrophomonas wolfet subsp wolfei subsp. nov. - and emended descriptions of the genus and species. Int J Sys Bacteriol 39:122-126

Mavrovouniotis ML (1991) Estimation of standard Gibbs energy changes of biotransformations. J Biol Chem 266:14440-14445

McInemey MJ (1988) Anaerobic hydrolysis and fermentation of fats and proteins. In: Zehnder AJB (ed) Biology of anaerobic microorganisms. John Wiley \& Sons, New York, pp 373-415

McInerney MJ, Bryant MP, Pfennig N (1979) Anaerobic bacterium that degrades fatty-acids in syntrophic association with methanogens. Arch Microbiol 122:129-135

McInerney MJ, Bryant MP, Hespell RB, Costerton JW (1981) Syntrophomonas wolfei gen. nov. sp. nov., an anaerobic, syntrophic, fatty-acid oxidizing bacterium. Appl Environ Microbiol 41 1029-1039

McInerney MJ, Struchtemeyer CG, Sieber J, Mouttaki H, Stams AJM, Schink B, Rohlin L. Gunsalus RP (2008) Physiology, ecology, phylogeny, and genomics of microorganisms capablc of syntrophic metabolism. Ann N Y Acad Sci 1125:58-72

Mountfort DO, Bryant MP (1982) Isolation and characterization of an anaerobic benzoate-degrading bacterium from sewage sludge. Arch Microbiol 133:249-256

Müller N, Worm P, Schink B, Stams AJM, Plugge CM (2010) Syntrophic butyrate and propionate oxidation processes: from genomes to reaction mechanisms. Environ Microbiol Rep 2:489-499

Plugge CM, Dijkema C, Stams AJM (1993) Acetyl-CoA cleavage pathway in a syntrophic propionate oxidizing bacterium growing on fumarate in the absence of methanogens. FEMS Microbiol Lett 110:71-76

Plugge CM, Balk M, Stams AJM (2002) Desulfotomaculum thermobenzoicum subsp thennosyntrophicum subsp nov., a thermophilic, syntrophic, propionate-oxidizing, spore-forming bacterium. Int I Syst Evol Microbiol 52:391-399

Roy F, Samain E, Dubourguier HC, Albagnac G (1986) Synthrophomonas sapovorans sp. nov., new obligately proton reducing anaerobe oxidizing saturated and unsaturated long-chain fatty acids. Arch Microbiol 145:142-147

Schink B, Stams AJM (2006) Syntrophism among prokaryotes. The prokaryotes: an evolving electronic resource for the microbiological community In: Dworkin M, Falkow S, Rosenberg B, Schleifer K-H, Stackebrandt E (eds), Springer-Verlag, New York, pp 309-335

Schink B, Thauer RK (1988) Energetics of syntrophic methane formation and the influence of aggregation. In: Lettinga G, Zehnder AJB, Grotenhuis JTC, Hulshoff Pol LW (eds), Granular anaerobic sludge; microbiology and technology, Pudoc, Wageningen, pp 5-17

Schirawski J, Unden G (1998) Menaquinone dependent succinate dehydrogenase of bacteria catalyzes reversed electron transport driven by the proton potential. Eur J Biochem 257:210-215 
Schmidt JE, Ahring BK (1993) Effects of hydrogen and formate on the degradation of propionate and butyrate in thermophilic granules from an upflow anaerobic sludge blanket reactor. App

Sekiguchi Y, Kamagata Y, Nakamura K, Ohashi A, Harada H (2000) Syntrophothermus lipocalidus gen. nov., sp. nov., a novel thermophilic, syntrophic, fatty-acid-oxidizing anaerobe which ut-

Sousa DZ, Smidt H, Alves MM, Stams AJM (2007) Syntrophomonas zehnderi sp. nov., an anaerobe that degrades long-chain fatty acids in co-culture with Methanobacterium formicicum. In J Syst Evol Microbiol 57:609-615

Sousa DZ, Smidt H, Alves MM, Stams AJM (2009) Ecophysiology of syntrophic communities that degrade saturated and unsaturated long-chain fatty acids. FEMS Microbiol Ecol 68:257-272 tams AJM (1994) Metabolic interactions between anaerobic bacteria in methanogenic environments. Antonie Van Leeuwenhoek 66:271-294

Stams AJM, Grolle KCF, Frijters CTMJ, Van Lier JB (1992) Enrichment of thermophilic propionate-oxidizing bacteria in syntrophy with Methanobacterium thermoautotrophicum or Methanobacterium thermoformicicum. Appl Environ Microbiol 58:346-352

Stieb M, Schink B (1985) Anaerobic oxidation of falty-acids by Clostridium bryantii sp. nov., a sporeforming, obligately syntrophic bacterium. Arch Microbiol 140:387-390

Svetlitshnyi V, Rainey F, Wiegel J (1996) Thermosyntropha lipolytica gen. nov., sp. nov., a lipolytic, anaerobic, alkalitolerant, thermophilic bacterium utilizing short- and long-chain fatty acids in syntrophic coculture with a methanogenic archaeum. Int J Syst Bacteriol 46:1131-1137

Thauer RK, Jungermann K, Decker K (1977) Energy conservation in chemotropic anaerobic bacteria. Bacteriol Rev 41:100-180

Thauer RK, Kaster AK, Seedorf H, Buckel W, Hedderich R (2008) Methanogenic archaea: ecologically relevant differences in energy conservation. Nat Rev Microbiol 6:579-591

Wallrabenstein C, Hauschild E, Schink B (1994) Pure culture and cytological properties of Syntrophobacter wolinii. FEMS Microbiol Lett 123:249-254

Wallrabenstein C, Hauschild E, Schink B (1995) Syntrophobacter pfennigii sp. nov., new syntrophically propionate-oxidizing anaerobe growing in pure culture with propionate and sulfate. Arch Microbiol 164:346-352

Wofford NQ, Beaty PS, McInemey MJ (1986) Preparation of cell-free extracts and the enzymes involved in fatty acid metabolism in Syntrophomonas wolfei. J Bacteriol 167:179-185

Worm P, Stams AJM, Cheng X, Plugge CM (2010) Growth and substrate dependent transcription of formate dehydrogenase and hydrogenase coding genes in Syntrophobacter fumaroxidans and Methanospirillum hungatei. Microbiology 157:280-289. doi:10.1099/mic.0.043927-0

Wu CG, Liu XL, Dong XZ (2006a) Syntrophomonas cellicola sp, nov., a spore forming syntrophic bacterium isolated from a distilled-spirit-fermenting cellar, and assignment of Syntrophospora bryantii to Syntrophomonas bryantii comb. nov. Int J Syst Evol Microbiol 56:2331-2335

Wu C, Liu X, Dong X (2006b) Syntrophomonas erecta subsp. sporosyntropha subsp.nov., a sporeforming bacterium that degrades short chain fatty acids in co-culture with methanogens. Syst Appl Microbiol 29:457-462

Wu CG, Dong XZ, Liu XL (2007) Syntrophomonas wolfei subsp. Methylbutyratica subsp. nov., and assignment of Syntrophomonas wolfei subsp. saponavida to Syntrophomonas saponavida sp. nov comb. nov. Syst Appl Microbiol 30:376-380

Zhang Y, Gladyshev VN (2005) An algorithm for identification of bacterial selenocysteine insertion sequence elements and selenoprotein genes. Bioinformatics 21;2580-2589

Zhang CY, Liu XL, Dong XZ (2004) Syntrophomonas curvata sp. nov., an anaerobe that degrades fatty acids in co-culture with methanogens. Int J Syst Evol Microbiol 54:969-973

Zhang CY, Liu XL, Dong XZ (2005) Syntrophomonas erecta sp. nov., a novel anaerobe that syntrophically degrades short-chain fatty acids. Int J Syst Evol Microbiol 55:799-803

Zhao HX, Yang DC, Woese CR, Bryant MP (1990) Assignment of Clostridium bryantii to Syntrophospora bryantii gen, nov, comb. nov on the basis of a $16 \mathrm{~S}$ ribosomal-RNA sequence analysis of its crotonte-grown pure culture. Int I Syst Bacteriol 40:40-44

\section{Chapter 9 \\ Anaerobic Digestion as an Effective Biofuel \\ Production Technology}

Serge R. Guiot and Jean-Claude Frigon

Abstract The methane produced from the anaerobic digestion of organic wastes and energy crops represents an elegant and economical mean of generating renewable biofuel. Anaerobic digestion is a mature technology and is already used for the conversion of the organic fraction of municipal solid wastes and primary and secondary sludge from wastewater treatment plant. High methane yield up to $0.45 \mathrm{Nm}^{3}$ $\mathrm{CH}_{4} / \mathrm{kg}$ volatile solids (VS) or $12,390 \mathrm{Nm}^{3} \mathrm{CH}_{4}$ /ha can be achieved with sugar and starch crops, although these cultures are competing for high quality land with food and feed crops. The cultivation of lignocellulosic crops on marginal and set-aside lands is a more environmentally sound and sustainable option for renewable energy production. The methane yield obtained from these crops is lower, $0.17-0.39 \mathrm{Nm}$ $\mathrm{CH}_{4} / \mathrm{kg}$ VS or $5,400 \mathrm{Nm}^{3} \mathrm{CH}_{4} / \mathrm{ha}$, as its conversion into methane is facing the same initial barrier as for the production of ethanol, e.g., hydrolysis of the crops. Intensive research and development on efficient pretreatments is ongoing to optimize the net energy production, which is potentially greater than for liquid biofuels, since the whole substrate excepted lignin is convertible into methane. Algal biomass is another alternative to food and feed crops. Their relatively high methane potential (up to $0.45 \mathrm{Nm}^{3} \mathrm{CH}_{4} / \mathrm{kg}$ VS fed) combined with their higher areal biomass productivity make them particularly attractive as a feedstock for an anaerobic digestionbased biorefinery concept.

Keywords Anaerobic digestion - Waste treatment • Energy crops • OLR • HRT - Wet and dry technologies $\bullet$ Energy yields $\bullet$ Microalgae biomethane potential

S.R. Guiot $(\mathbb{\otimes})$ - J.-C. Frigon

Biotechnology Research Institute, National Research Council of Canada, 6100 Royalmount, Montreal, QC, Canada

e-mail: serge.guiot@cnrc-nrccgc.ca 